\title{
Phenotypic correlations of field and laboratory tests with honey production in Africanized honey bees (Apis mellifera)*
}

\author{
Oscar ZÁRATE ${ }^{1}$, Chavier De ARAUjo-FreITAS ${ }^{1}$, Luis A. MEdinA ${ }^{1}$, \\ Alfonso VELÁsQUEZ ${ }^{2}$, J. Javier G. QUEZADA-EUÁN ${ }^{1}$ \\ ${ }^{1}$ Universidad Autónoma de Yucatán, Facultad de Medicina Veterinaria, Departamento de Apicultura, Apartado \\ Postal 4-116 CP 97100, Mérida, Yucatan, Mexico \\ ${ }^{2}$ Instituto Tecnológico Agropecuario 2, Conkal Yucatan, Mexico
}

Received 6 March 2008 - Revised 2 May 2008 - Accepted 5 May 2008

\begin{abstract}
Africanized honey bees (Apis mellifera; AHB) are predominant in tropical Mexico. A selection program using local AHBs colonies is a good alternative to provide beekeepers with good quality queens. We evaluated the application of field and laboratory tests to predict the production of honey in AHBs from Yucatan, Mexico. Five variables were measured in worker bees in the laboratory: longevity, amount of syrup removed, hoarding, weight of pupae and corbicular area. Three additional variables were measured in the field: rate of foraging activity, volume of honey sac contents and colony weight gain per week. Our results showed that weekly colony weight gain had the highest correlation with honey production in AHBs. Only the corbicular area and worker longevity were not correlated with honey production $(r=0.256$ and $r=0.074$, respectively $P>0.05$ ). Thus, short term colony weight gain can be recommended as a good estimate of honey production in AHBs and lab tests can be included as selection aids.
\end{abstract}

Africanized honey bees / phenotypic correlation / honey production / Yucatan / queen bee / breeding

\section{INTRODUCTION}

Mexico is the third largest honey exporter in the world and its tropical areas, namely the Yucatan Peninsula and the Gulf Region, produce the largest amount of honey within the country. The high concentration of hives in those areas creates a large annual demand for queen honey bees that presently derive from European stocks (Zamora et al., 2008).

Africanized honey bees (AHBs) expanded from Brazil across the American tropics arriving in the southern border of Mexico in 1986 (Kerr, 1967; Fierro et al., 1987) and gradually colonized all the country, becoming predominant in the tropical and subtropical regions (Clarke et al., 2002; Quezada-Euán, 2007). In

Corresponding author: C.D. Araujo-Freitas, afreitas@uady.mx

* Manuscript editor: Stan Schneider these areas, preserving pure European-derived stocks in breeding apiaries relies on the importation of queens which is costly and carries the risk of bringing diseases into the country (Quezada-Euán et al., 2005). Intense swarming and defense are regarded as some of the most negative features of AHBs (Rinderer and Hellmich, 1991; Guzmán-Novoa and Page, 1999); however, these bees may have advantages such as their resistance to parasites and disease (Medina and Martin, 1999) and their adaptation to tropical climates. Therefore, a selection program can potentially improve local AHBs for production purposes. A breeding program using $\mathrm{AHBs}$ was started in the $\mathrm{Yu}-$ catan Peninsula in 2003 with the aim of producing manageable colonies with high honey production (Quezada-Euán et al., 2005).

AHBs show marked differences with European bees in the dynamics of colony 
growth and strategies of exploitation of floral resources (Rinderer and Hellmich, 1991; Winston, 1992). Thus, the components of nectar storage and handling leading to honey production may differ between both bee types. The use of laboratory tests has been proposed to evaluate components of honey production in European honey bees (EHBs) (Milne, 1985). Such tests have not been evaluated in breeding programs using AHBs.

In honey bee breeding programs, the use of field performance of whole colonies shows some disadvantages, such as the large numbers of bees that are required, the length of time needed for the workers in a colony to be the product of a new queen and the difficulty to control environmental conditions. The use of laboratory tests has advantages, such as the small number of workers required, a reduced time for the tests and the possibility of measuring the responses under carefully controlled conditions (Kulincevic and Rothenbuhler, 1973; Kulincevic et al., 1974; Milne, 1977, 1985). These advantages have stimulated the development of tests in the laboratory to determine the honey gathering potential of colonies of honeybees (Rinderer and Baxter, 1978; Milne, 1985; Poklukar and Gregorc, 1994).

Even though genetic correlations of laboratory measured traits with honey production have not been calculated, the phenotypic correlations of such traits with honey production suggest that some of them (such as pupal weight, corbicular area, honey sac contents, worker longevity or length of life, foraging activity and hoarding of syrup storage) might be useful as parameters of colony evaluation and could be used in selection for honey production in breeding programmes with EHBs (Kulincevic and Rothenbuhler, 1973; Milne, 1980a, b, c; 1981a, b; Szabo, 1982; Milne and Friars, 1984).

The objective of the present work was to evaluate the use of laboratory and field tests to predict the potential honey production in AHBs colonies. The degree of association (phenotypic correlation) between components of honey production was calculated to establish a selection index in AHBs.

\section{MATERIALS AND METHODS}

The experiments were conducted at the Campus of Biological Sciences and Animal Husbandry of the Autonomous University of Yucatan $\left(20^{\circ} 48^{\prime} \mathrm{N}\right.$ and $89^{\circ} 47^{\prime} \mathrm{W}$ ). The climate in this region is tropical sub humid with a rainy season in the summer. The average annual temperature is $25.9{ }^{\circ} \mathrm{C}$ and rainfall is $1290 \mathrm{~mm}$ (García, 1981).

Twenty five colonies of honey bees were randomly selected and the queens were marked on the thorax. The age of the queens was between 7-10 months. To confirm the racial origin of the colonies, samples of workers were taken from the brood combs and kept in ethanol. Routine measures of forewing and femur length on 10 workers per colony were used to calculate the probability of Africanization using the FABIS method (Sylvester and Rinderer, 1987). Additionally, the mitotype of the queen was determined by analyzing the mtDNA of a single worker per colony using the PCR-RFLP methods by Nielsen et al. (1999).

All colonies were maintained in Langstroth type hives and were homogenized in the number of combs with caped brood (3), open brood (2), pollen (2) and honey (2). An exact estimation of the population of workers and brood cells was conducted by taking pictures of each brood comb and the total number of combs covered by adult bees. Later on these pictures were loaded onto a PC and the numbers of adult bees and brood cells were counted using the method by Rogers et al. (1983).

The experiments were conducted in from February to April 2004 during the flowering season. Four variables were measured in the laboratory: hoarding activity, worker longevity, weight of pupae and corbicular area. Three additional variables were measured in the field: colony foraging activity, volume of honey sac contents and colony weight gain per week.

\subsection{Laboratory tests}

Longevity was estimated using the method of Kulincevic and Rothenbuhler (1973). Combs with sealed brood from each experimental colony were taken to the lab where the young bees emerged in an incubator $\left(34-35{ }^{\circ} \mathrm{C}\right.$ and $50 \%$ R.H.). Two trials were conducted with three replications from each colony. Each replication consisted of 50 bees ( $<$ one day of age) kept in experimental wooden cages $(11.5 \times 8.5 \times 7.5 \mathrm{~cm})$. A segment of empty old 
comb was weighed and provided to each group of bees (ca. $80 \mathrm{~cm}^{2}$ ) (Rinderer and Elliot, 1977). Two feeders with water and sugar syrup were also provided to each box and their contents changed every 2 days. Daily records of the number of dead bees were taken for each box. The average life span was considered as the day by which $50 \%$ of the bees died in a box. The bees that died during the first week of the experiment were not considered since they could have died due to the stress of handling (Milne, 1982).

Hoarding, considered as the storage of syrup, was evaluated in cages in the same groups of bees used for the estimation of longevity (as in Poklukar and Gregorc, 1994). The segment of old comb that was provided to each box was removed after 14 days and weighed again using an analytic scale in order to determine the amount of sugar syrup stored by the bees. A recording of the amount of syrup removed by the bees from the feeder was made every 2 days and the total removed during the trial was considered food consumption.

The weight of the pupae was recorded using the method of Viera (1990). In each experimental colony, the queen was caged to induce egg laying on a new comb. In this way the exact age of the pupae in that comb could be established. Thirteen days later, 25 pupae with pink eyes were collected in the lab from each experimental comb and weighed with an analytical scale; the average weight was used as the indicator of worker pupal weight per colony. The procedure was repeated twice for each experimental colony.

The area of the corbicula was also estimated for each experimental colony using the method of Milne and Pries (1984). A sample of young bees were collected from the brood area and kept in ethanol. In the lab the hind leg of 20 bees from each sample was removed and mounted on a slide. The length and width of each corbicula was obtained in microns using an inverted microscope (Summagraphics $\mathrm{II}^{\circledR}$ ) and the program AFUSDA (Rubink, unpubl. data). The corbicular area was calculated using the formula for a triangle. Corbicular areas were measured twice in each colony.

\subsection{Field tests}

Colony foraging activity was estimated using the method of Szabo (1980). Counts of the number of bees entering the hive in five minutes were conducted in each experimental colony three times. All colonies were evaluated on the same days and at the same time every two hours (between $8000 \mathrm{~h}$ and $1400 \mathrm{~h}$ ) on two occasions.

The volume of the contents of the honey sac was evaluated at the same time as the foraging activity using the method of Gary and Lorenzen (1976). Returning bees were captured and a slight pressure was applied with the fingers on their abdomen to stimulate regurgitation. The contents of the sac were collected in graduated capillary tubes to estimate the volume. Five bees were measured from each colony every two hours between $8000 \mathrm{~h}$ and $1400 \mathrm{~h}$. The recording of this variable was done twice.

The weight of each colony was registered every week during 10 weeks using a Roman type scale (Wagner ${ }^{\circledR}$ ). The net weight gain was obtained by subtracting the weight of the equipment to the total weight obtained every week.

Colony honey production was estimated at the end of the flowering season by harvesting all the honey combs with at least $80 \%$ of their cells capped. The total number of combs was multiplied by an estimated $1.8 \mathrm{~kg}$ of honey per comb to obtain the total amount of honey per colony (Estrada de la Mora and Guzmán-Novoa, 1991).

\subsection{Statistical analyses}

A covariance analysis was used to remove the effect of the number of adult bees and brood when the experimental colonies were formed using the PROC GLM procedure of the SAS statistical software (1990 version 6.1). After this, we conducted Pearson's simple correlations to evaluate the relationship of the field and laboratory estimates with honey production using the PROC CORR command. The variables with the highest correlations with honey production were later included in the construction of a linear regression model to predict honey production in Africanized honey bee colonies using the PROC GLM command.

\section{RESULTS}

All the experimental colonies were determined as Africanized with a probability $>0.99$ in accordance to FABIS (Sylvester and Rinderer, 1987). This was further confirmed with the PCR-RFLP analysis which showed that all experimental colonies were headed by queens with African mitotypes. The average 
adult population in the experimental colonies was $22133 \pm 2154$ workers.

Honey production was obtained at the end of the flowering season in April. The average amount of honey produced was $26.5 \pm 7.27 \mathrm{~kg}$ (range $13.5-34.5 \mathrm{~kg}$ ).

The results of the analysis of covariance showed that there was no significant influence of the adult and brood population at the start of the experiments on honey production ( $r=0.24, n=24, P>0.05)$. This was probably a consequence of the standardization method used when the experimental colonies were formed. Therefore, it was decided not to include these covariables in further analyses.

The results of the correlations amongst all variables are presented in Table I.

\subsection{Laboratory tests}

The average worker longevity in AHBs was $29.2 \pm 2.06$ days. Although the variation in worker longevity between colonies was significant $(\mathrm{F}=11.81$, $\mathrm{df}=23,168, P<0.05)$, this variable was not correlated with honey production $(r=0.07, P>0.05$; Tab. I).

The caged workers hoarded $8.6 \pm 1.63 \mathrm{~g}$ of syrup every 2 days. There was a significant correlation between the amount of syrup hoarded by the caged workers and the honey production of their natal colony $(r=0.43, P<$ 0.05 ; Tab. I). There were also significant differences in hoarding between colonies $(\mathrm{F}=2.36$, df $=23,168, P<0.01)$. The consumption of syrup in the 2 days was $9.19 \pm 3.1 \mathrm{~mL}$ and there were significant differences between colonies $(\mathrm{F}=2.58, \mathrm{df}=23,168, P<0.01)$. There were significant correlations between the amount of syrup removed by the caged bees and colony honey production $(\mathrm{r}=0.59, \mathrm{n}=24, P<0.01)$.

The average weight of pink-eyed pupae was $111.8 \pm 0.004 \mathrm{mg}$. This variable showed a significant correlation with honey production $(r=$ $0.42, P<0.05$; Tab. I). There were significant variations between colonies for this character $(\mathrm{F}=3.51, \mathrm{df}=23,2376, P<0.01)$.

The corbicular area was on average $1.516 \pm$ $0.042 \mathrm{~mm}^{2}$ and there was no significant correlation with honey production $(r=0.09$,
$P>0.05$; Tab. I), although there were significant differences between colonies $(\mathrm{F}=3.26$, df $=23,1896, P<0.01)$.

\subsection{Field tests}

Field tests had higher correlations with honey production, compared with laboratory tests.

The average colony weight gain per week was $3.19 \pm 2.06 \mathrm{~kg}$. This variable had the highest correlation with honey production $(r=$ $0.84, P<0.01$; Tab. I).

The average volume of the honey sac of returning foragers was $30.02 \pm 2.64 \mu \mathrm{L}$ and this variable had the second highest correlation with honey production $(r=0.70, P<0.01)$ with significant differences between colonies $(\mathrm{F}=2.95, \mathrm{df}=23,48, P<0.05)$.

Colony foraging activity estimated as the number of bees entering the hive in $5 \mathrm{~min}$ was $68.98 \pm 50.49$ and it had the third highest correlation with honey production $(\mathrm{r}=0.61$, $P<0.05$; Tab. I). There were significant differences between colonies for this variable (F $=6.09$, df $=23,48, P<0.01)$.

A regression analysis revealed that with the inclusion of all the variables measured in this work, $87 \%$ of the honey produced could be predicted. However, since measuring all those variables would mean a difficult task, other models were constructed removing some of the variables with the lowest correlations. When only the variables with significant correlations with honey production, except weekly weight gain, were included in the model the regression was significant $\left(R^{2}=0.60, \mathrm{df}=5\right.$, 18 , ee $=3.73$ ). When the weekly weight gain was included in the model the variability explained increased $\left(R^{2}=0.79\right.$, df $=6,17$, ee $=2.79$ ). We decided to exclude the volume of the honey sac and foraging activity from the equation, given the difficulty in measuring these variables and their high correlation with pupal weight. The revised model explained $74 \%$ of the variation in colony honey production $\left(R^{2}=0.74\right.$, df $=4,19$ ee $\left.=2.89\right)$.

Thus, a final equation including hoarding (hd), food consumption (fc), weight gain (wg) and pupal weight (pw) for the estimation of 
Table I. Correlations between total honey production and the eight components evaluated in the field and in the lab in Africanized honey bees. The value of $P$ is in brackets.

\begin{tabular}{|c|c|c|c|c|c|c|c|c|}
\hline & $\begin{array}{l}\text { Weight } \\
\text { Gain }\end{array}$ & $\begin{array}{l}\text { Honey Sac } \\
\text { Volume }\end{array}$ & $\begin{array}{l}\text { Foraging } \\
\text { Activity }\end{array}$ & Hoarding & $\begin{array}{l}\text { Syrup } \\
\text { Removed }\end{array}$ & $\begin{array}{l}\text { Pupal } \\
\text { Weight }\end{array}$ & $\begin{array}{l}\text { Corbicular } \\
\text { Area }\end{array}$ & Longevity \\
\hline $\begin{array}{l}\text { Honey } \\
\text { Production }\end{array}$ & $\begin{array}{l}0.842 \\
(0.001)\end{array}$ & $\begin{array}{l}0.702 \\
(0.001)\end{array}$ & $\begin{array}{l}0.619 \\
(0.001)\end{array}$ & $\begin{array}{l}0.438 \\
(0.032)\end{array}$ & $\begin{array}{l}0.598 \\
(0.002)\end{array}$ & $\begin{array}{l}0.429 \\
(0.036)\end{array}$ & $\begin{array}{l}0.256 \\
(0.227)\end{array}$ & $\begin{array}{l}0.074 \\
(0.729)\end{array}$ \\
\hline WG & & $\begin{array}{l}0.704 \\
(0.001)\end{array}$ & $\begin{array}{l}0.703 \\
(0.001)\end{array}$ & $\begin{array}{l}0.367 \\
(0.037)\end{array}$ & $\begin{array}{l}0.626 \\
(0.001)\end{array}$ & $\begin{array}{l}0.569 \\
(0.004)\end{array}$ & $\begin{array}{l}0.284 \\
(0.177)\end{array}$ & $\begin{array}{l}0.109 \\
(0.610)\end{array}$ \\
\hline HSV & & & $\begin{array}{l}0.662 \\
(0.001)\end{array}$ & $\begin{array}{l}0.479 \\
(0.015)\end{array}$ & $\begin{array}{l}0.614 \\
(0.001)\end{array}$ & $\begin{array}{l}0.470 \\
(0.012)\end{array}$ & $\begin{array}{l}0.150 \\
(0.484)\end{array}$ & $\begin{array}{l}0.207 \\
(0.330)\end{array}$ \\
\hline FA & & & & $\begin{array}{l}0.510 \\
(0.011)\end{array}$ & $\begin{array}{l}0.744 \\
(.001)\end{array}$ & $\begin{array}{l}0.495 \\
(0.010)\end{array}$ & $\begin{array}{l}0.219 \\
(0.301)\end{array}$ & $\begin{array}{l}0.004 \\
(0.985)\end{array}$ \\
\hline HB & & & & & $\begin{array}{l}0.678 \\
(0.001)\end{array}$ & $\begin{array}{l}-0.084 \\
(0.696)\end{array}$ & $\begin{array}{c}-0.068 \\
(0.749)\end{array}$ & $\begin{array}{l}0.017 \\
(0.936)\end{array}$ \\
\hline SR & & & & & & $\begin{array}{l}0.481 \\
(0.017)\end{array}$ & $\begin{array}{l}0.241 \\
(0.256)\end{array}$ & $\begin{array}{l}-0.159 \\
(0.456)\end{array}$ \\
\hline PW & & & & & & & $\begin{array}{l}0.415 \\
(0.043)\end{array}$ & $\begin{array}{l}-0.006 \\
(0.974)\end{array}$ \\
\hline $\mathbf{C A}$ & & & & & & & & $\begin{array}{l}-0.333 \\
(0.111)\end{array}$ \\
\hline
\end{tabular}

honey production in Africanized honey bee colonies was selected and expressed as:

Honey production $=8.928-1.394(\mathrm{hd})+$ $0.223(\mathrm{fc})+1.732(\mathrm{wg})-32.779(\mathrm{pw})$.

The real data of honey production per colony was compared to the one predicted with the regression equation. The latter was obtained by substituting each character in the equation above with the real values obtained per colony. A highly significant correlation with the amount of honey obtained and the predicted value was found ( $r=0.86, n=24$, $P<0.01)$.

\section{DISCUSSION}

Our results showed that weekly weight gain had the highest correlation with honey production in AHBs. This variable can be measured quickly and with minimal colony disturbance in the field. Thus, short term weight gain can be recommended as a good estimate of honey production in a selection program with AHBs.

Honey production is the result of a complex interaction between several components. It has been suggested that some traits related to the morphology and behavior of the workers may be useful to predict the honey production in full colonies of European races.
However, when different bees in different locations (climates) are evaluated, it is necessary to determine the existence of consistent relationships between such components and honey production (Kulincevic et al., 1974). We evaluated eight characteristics in AHBs in tropical climates that were formerly identified as important components of honey production in EHBs in temperate climates. From these, six were found to have significant correlations with honey production. These results suggest that components of honey production can be effectively measured using laboratory tests in AHBs as well as in European bees. The argument of measuring some variables through laboratory tests in breeding programs for improved honey production with AHBs is thus supported.

Length of worker life and corbicular area correlated well with honey production in EHBs (Milne, 1981; Kulincevic and Rothenbuhler, 1982; Milne and Pries, 1984; Milne et al., 1986). However, our results revealed that these two characters were not important in predicting honey production in AHBs.

Empirical data show that AHBs start foraging earlier and have a shorter life span than EHBs (Winston and Katz, 1981; Pankiw, 2003). Moreover, in AHBs, our results suggest 
that workers from colonies that produced more honey did not necessarily live longer, and those from low producing colonies may not necessarily have shorter lives. These results could be explained, if under tropical conditions, worker life span would be more related to colony reproduction rather than honey accumulation. In fact, AHBs follow a strategy linked to intense exploitation of food resources to reproduce and swarm rather than for storage (Schneider et al., 2004).

Our results also contrast with findings in European colonies that reported high correlations between a large corbicular area in the workers and their honey production (Milne and Pries, 1984). It is suggested that an increased pollen collection by colonies of bees with larger corbiculae results in an increased egg-laying rate and brood area and better fed brood with a longer adult life, both of which would increase colony population and honey production (Milne and Pries, 1984, 1986). However, in AHB colonies, it seems that a higher proportion of the workers are devoted to pollen collection for brood production rather than nectar gathering (Schneider et al., 2004); thus, the relationship between the size of the pollen collecting apparatus and honey production would be less evident than in European bees.

We found that in AHBs hoarding activity correlated well with honey production as in EHBs (Rinderer and Baxter, 1978). We also found that the volume of syrup removed by AHBs was comparatively similar to that previously reported for European bees (Winston, 1992; Viera, 1990). This finding differs from that of Rinderer et al. (1986) who found that EHBs hoarded sugar solution more efficiently than AHBs. However, these authors also suggested that variable hoarding rates may be found in AHBs leading to successful exploitation of nectar resources under changing environmental conditions (Rinderer et al., 1982). In the tropics, low hoarding rates may be related to an efficient use of nectar for self maintenance in harsh conditions but in times of good nectar flow AHBs could store the surplus nectar as EHBs do.

Weekly colony weight gain had the highest correlation with honey production in AHBs.
Measuring all other characteristics can be difficult and tedious, whereas colony weight gain can be easily measured and reflects the interaction of all these factors in just one measurement. Thus, we recommend using short term weight gain as the preferred option for predicting seasonal honey production (Szabo, 1982) if no other method would be available.

Field tests are more influenced by environmental factors and the inclusion of laboratory tests would add a controlled element to the results. This would also allow more substantial progress with the advantages of increasing repeatability (Milne, 1985). Thus, when possible, the use of some lab parameters in addition to colony weight gain may be valuable aids in deciding colony selection in AHBs. The results of the high correlations obtained between the different components led us to propose a model that predicted honey production in AHBs above $85 \%$, including weekly weight gain, hoarding, food consumption and pupal weight. The latter 3 components can be easily measured and repeated in the lab.

\section{ACKNOWLEDGEMENTS}

This research was founded by project SAGARPA-CONACYT (2002-1556). We thank Omar Zamora, Manuel Cocom and Laura Saldivar for field assistance.

Corrélations phénotypiques des tests en champ et au laboratoire avec la production de miel chez les abeilles africanisées (Apis mellifera).

abeille africanisée / corrélation phénotypique / prédiction / production de miel / élevage de reines / Yucatan / Mexique

Zusammenfassung - Phänotyp-Korrelationen von Parametern aus Labor- und Feldversuchen mit der Honigproduktion Afrikanisierter Honigbienen (Apis mellifera). Afrikanisierte Honigbienen (AHBs) haben sich in den subtropischen Regionen Mexikos inzwischen fest etabliert. Will man in diesen Gebieten reine Rassen europäischen Ursprungs halten, so ist man auf kostspielige Importe von Königinnen angewiesen, die andererseits das Risiko der Einschleppung von Krankheiten mit sich bringen. AHBs bringen ihrerseits Vorteile mit sich, wie z.B. eine höhere Toleranz gegen Parasiten und Krankheiten, sowie ihre allgemeine Anpassung an 
tropische Klimate. Ein auf Produktion abzielendes Selektionsprogramm könnte daher dazu beitragen, lokale AHBs zu verbessern.

Wir wählten nach Zufallskriterien 25 AHB Völker aus und markierten deren Königinnen auf dem Thorax. Alle Völker wurden in Langstroth-Beuten gehalten und wurden bezüglich ihrer Wabenzahl, Brutmenge und Futtervorräten gegenseitig angeglichen. Im Labor quantifizierten wir dann an Arbeiterinnen die folgenden Parameter: Lebensdauer, entnommene Menge an Zuckerlösung, Futtereinlagerung, Puppengewicht und Pollenkörbchengrösse. Ausserdem evaluierten wir noch drei Parameter in Feldversuchen: Sammelaktivität, Honigblasenvolumen und wöchentliche Gewichtszunahme der Völker.

Zur Bestimmung der Lebensdauer wurden Arbeiterinnen in Käfigen in einem Brutschrank solange gehalten, bis $50 \%$ der Bienen gestorben waren. Die Futtereinlagerung wurde unter den gleichen Haltungsbedingungen durch Zugabe eines Stücks alter Wabe gemessen. Dieses wurde nach 14 Tagen entfernt und gewogen, um die Menge eingelagerter Zuckerlösung zu bestimmen. In den Versuchsvölkern wurden die Königinnen gekäfigt und die Eiablage auf frischen Waben induziert, um Puppen genaue bestimmten Alters zu erhalten. Nach 13 Tagen wurden die rosaäugigen Puppen aus den Waben entnommen und gewogen. Die Corbicula-Grösse wurde an jeweils 20 jungen Arbeiterinnen bestimmt, die von Waben abgesammelt wurden

Das Sammelverhalten wurde anhand von Zählungen von Bienen quantifiziert, die in Intervallen von 5 Minuten in den Stock einflogen. Zur Bestimmung des Honigblasenvolumens wurde das Abdomen von Arbeiterinnen leicht zwischen den Finger gepresst. Dies stimulierte sie zur Regurgitation des Honigbaseninhalts, der dann mittels graduierter Kapillaren vermessen werden konnte.

Die Gewichtszunahme der Völker wurde wöchentlich über einen Zeitraum von 10 Wochen registriert. Das Nettogewicht ermittelten wir durch Abzug des Gerätegewichts vom Gesamtgewicht.

\section{Afrikanisierte Honigbienen / Phänotyp- Korrelation / Honigproduktion / Yucatán / Königin / Zuchtprogramm}

\section{REFERENCES}

Clarke K.E., Rinderer T.E., Franck P., Quezada-Euán J.J.G., Oldroyd B.P. (2002) The Africanization of honey bees (Apis mellifera L.) of the Yucatan: a study of a massive hybridization event across time, Evolution 56, 1462-1474.

Estrada de la Mora E., Guzmán-Novoa E. (1991) Selección práctica para alta producción de miel en abejas melíferas (Apis mellifera L.), in: Memorias del V seminario Americano de Apicultura, Guadalajara, Jalisco, pp. 69-71.

Fierro M.M., Barraza A., Maki D.L., Moffet J.O. (1987) The effects of the first year of Africanization on honey bee populations in Chiapas, México, Am. Bee J. 127, 845.

García E. (1981) Modificaciones al sistema de clasificación climática de Koppen para adaptarlo a las condiciones de la República Mexicana. Instituto de Geografía, UNAM, 252 p.

Gary N.E., Lorenzen K. (1976) A method for collecting the honey-sac contents from honeybees, J. Apic. Res. 15, 73-79.

Guzmán-Novoa E., Page R.E. Jr. (1999) Selective breeding of honey bees (Hymenoptera: Apidae) in Africanized areas, J. Econ. Entomol. 92, 521-525.

Kerr W.E. (1967) The history of the introduction of Africanized bees in Brasil, S. Afr. Bee J. 39, 35 .

Kulincevic J.M., Rothenbuhler W.C. (1973) Laboratory and field measurements of hoarding behavior in honeybee (Apis mellifera L.), J. Apic. Res. 12, 179-182.

Kulincevic J.M., Thompson V.C., Rothenbuhler W.C. (1974) Relationship between laboratory tests of hoarding behavior and weight gained by honeybee colonies in the field, Am. Bee J. 114, 93-94.

Kulincevic J.M., Rothenbuhler W.C. (1982) Selection for length of life in the honeybee (Apis mellifera L.), Apidologie 13, 347-352.

Medina M.L., Martin S.J. (1999) A comparative study of Varroa jacobsoni reproduction in worker cells of honey bees (Apis mellifera) in England and Africanized bees in Yucatan, Mexico, Exp. Appl. Acarol. 23, 659-667.

Milne C.P. Jr. (1977) An improved laboratory measurement of hoarding behavior in the honeybee, Am. Bee J. 117, 502, 507.

Milne C.P. Jr. (1980a) Laboratory measurement of honey production in the honey bee. 3. Pupal weight of the worker, J. Apic. Res. 19, 176-178.

Milne C.P. Jr. (1980b) Laboratory measurement of honey production in the honey bee. 2. Longevity or length of life of caged workers, J. Apic. Res. $19,172-175$.

Milne C.P. Jr. (1980c) Laboratory measurement of honey production in the honeybee. I. A model for hoarding behavior by caged workers, J. Apic. Res. $19,122-126$.

Milne C.P. Jr. (1981a). Laboratory measurement of honey production in the honeybee. 4 . Relationship between responses on tests of hoarding, longevity or length of life and pupal weight of the worker, J. Apic. Res. 20, 28-30.

Milne C.P. Jr. (1981b) Laboratory measurement of honey production in the honeybee. 5. Relationship 
between weekly colony weight gains, and responses on tests of hoarding behaviour, longevity or length of life and pupal weight of the worker, J. Apic. Res. 20, 31-33.

Milne C.P. Jr. (1982) Early death of newly emerged worker honeybees in laboratory test cages, J. Apic. Res. 21, 107-110.

Milne C.P. Jr. (1985) The need for using laboratory tests in breeding honeybees for improved honey production, J. Apic. Res. 24, 237-242.

Milne C.P. Jr., Friars G.W. (1984) An estimate of the heritability of honeybee pupal weight, J. Hered. 75, 509-510.

Milne C.P. Jr., Pries K.J. (1984) Honey bee corbicular size and honey production. J. Apic. Res. 23, 1114.

Milne C.P. Jr., Pries K.J. (1986) Honeybees with larger corbiculae carry larger pollen pellets, J. Apic. Res. 25, 53-54.

Nielsen D.I., Ebert P.R., Hunt G.J., Guzmán-Novoa E., Kinee S.A., Page R. Jr. (1999) Identification of Africanized honey bees (Hymenoptera: Apidae) incorporating morphometrics and an improved polymerase chain reaction mitotyping procedure, Ann. Entomol. Soc. Am. 92, 167-174.

Pankiw T. (2003) Directional change in a suite of foraging behaviors in tropical and temperate evolved honey bees (Apis mellifera L.), Behav. Ecol. Sociobiol. 54, 458-464.

Poklukar J., Gregorc A. (1994) Repeatability of hoarding behavior of honeybee workers (Apis mellifera carnica Polm) in laboratory test cages, Apidologie 25, 350-352.

Quezada-Euán J.J.G. (2007) A retrospective history of the expansion of Africanized honeybees in México, J. Apic. Res. 46, 295-300.

Quezada-Euán J.J.G., De Araujo-Freitas C., Marrufo J.C., Velásquez M.A., Medina L.A., Pech F.G. (2005) Avances en el programa de mejoramiento genético apícola de la FMVZ-UADY, in: XIX Seminario Americano de Apicultura. Campeche, México, pp. 83-86.

Rinderer T.E., Elliot K.D. (1977) The effect of a comb on the longevity of caged adult honey bees, Ann. Entomol. Soc. Am. 70, 365-366.

Rinderer T.E., Baxter J.R. (1978) Honey bees: Effect of group size on longevity and hoarding in laboratory cages, Ann. Entomol. Soc. Am. 71, 732.
Rinderer T.E., Hellmich R.L. (1991) The processes of Africanization, in: Spivak M., Fletcher D.J.C., Breed M.D. (Eds.), The "African" honey bee, Westview Press, Boulder Colorado.

Rinderer T.E., Bolten A.B., Harbo J.R., Collins A.M. (1982) Hoarding behavior of European and Africanized honeybees (Hymenoptera: Apidae), J. Econ. Entomol. 75, 714-715.

Rinderer T.E., Collins A.M., Hellmich R.L., Danka R.G. (1986) Regulation of the hoarding efficiency of Africanized and European honey bees, Apidologie 17, 227-232.

Rogers L.E., Gilbert R.O., Burgett M. (1983) Sampling honeybee colonies for brood production: a double sampling technique, J. Apic. Res. 22, 232-241.

SAS Institute Inc. (1990) SAS/STAT User's guide, version 6, 4th edition, Cary, SAS Institute Inc, North Carolina.

Schneider S.S., Degrandi-Hoffman G., Smith D.R. (2004) The African honey bee: factors contributing to a successful biological invasion, Annu. Rev. Entomol. 49, 351-376.

Sylvester H.A., Rinderer T.E. (1987) Fast Africanized bee identification system FABIS), Am. Bee J. 127, 511-516.

Szabo T.I. (1980) Effect of weather factors on honey bee flight activity and colony weight gain, J. Apic. Res. 19, 164-171.

Szabo T.I. (1982) Phenotypic correlations between colony traits in the honey bee, Am. Bee J. 122, 711-716.

Viera C.F.A. (1990) Field and laboratory tests in breeding programme of honeybees (Apis mellifera L.) to improve honey production, Master of Philosophy Thesis, School of Pure and Applied Biology, University of Wales College of Cardiff, United Kingdom.

Winston M.L. (1992) The biology and management of Africanized honey bees, Annu. Rev. Entomol. 37, 173-193.

Winston M.L., Katz S.J. (1981) Longevity of crossfostered honey bee workers (Apis mellifera) of European and Africanized races, Can. J. Zool. 59, 1571-1575.

Zamora O., Quezada-Euán J.J.G., Alaniz-Gutierrez L., Dominguez R. (2008) Frequency of European and African-derived morphotypes and haplotypes in colonies of honey bees (Apis mellifera L.) from NW México, Apidologie 39, 388-396. 